\title{
Non-Governmental Organizations (NGOS) and Rural Development in Nigeria
}

\author{
Ngeh, David Baride \\ Department of Social Studies \\ Ignatius Ajuru University of Education, \\ Port Harcourt, Nigeria.
}

\section{Doi:10.5901/mjss.2013.v4n5p107}

\begin{abstract}
There is an increasing desire for the development of rural areas in Nigeria because of its strategic importance. Successive governments have made frantic efforts aimed towards the development of the rural areas. Such efforts include the operation feed the Nation progreamme; the River basin and Rural Development Authorities; Directorate of food, road and Rural Infrastructure; Better life for Rural Women; the family support programme; family Economic Advancement Programme; and the National Directorate of Employment. Unfortunately, all the efforts made by successive administrations have not achieved desired goal. In recent times, non-governmental organizations have participated in rural development to compliment the efforts of government. Some of their contributions include human capital development and technical assistance; Development of Small Scale farmers; Research, monitoring and evaluation; Enlightenment Campaigns; Advocacy for the poor; and conflict resolution/peace building. However, the non-governmental organizations have some challenges which have limited their performances and also impeded their growth. Based on the findings, it has been recommended that Government should embark on aggressive development of the rural areas. Similarly, NGOs at the various levels should partner and work in collaboration.
\end{abstract}

\section{Introduction}

The problem of rural development in Nigeria have been of great concern to the different tiers of government due to the alarming rate of rural-urban migration. According to Onibokum (1987), rural development is faced with the paradox that the development oriented rural economy relies heavily on non-productive people who are ill-equipped with outdated tools, lack technical information, lack scientific and cultural training, and whose traditional roles and access to resources pose problems for their effective incorporation into modern economic system.

There is an overwhelming need to accord rural development a priority so as to enable them contribute meaningfully to the socio-cultural and socio-economic development of Nigeria. The bulk of Nigeria's wealth is derived from agriculture and oil which lies in abundant quantity in rural communities. Currently, over $80 \%$ of the entire population live in the rural area, but much has not been done in terms of social amenities and infrastructural facilities. The neglect of the rural areas has not only resulted to the mass exodus of rural dwellers to the urban centres, but has also made the rural areas less attractive for socio-economic investment.

Ariyo (1991) asserts that the massive rural-urban drift of able-bodied young men and women led to declining productivity in agriculture, increasing food imports, growing unemployment and the widening gap in welfare terms between the urban and rural areas. Related studies affirmed that rural areas of Nigeria are areas where the lack of basic socio-economic infrastructures, poverty, and conflict have become a strong push factor for rural out-migration. 


\section{Definition of Concepts}

\section{Non-Governmental Organizations (NGOs)}

An organization is a collection of people working in a coordinated manner to achieve a common purpose. There are many types of organizations, which may be classified as either for-profit or not-for-profit (nonprofit), large or small.

Non-Governmental organizations are organizations that operate across national boundaries, that have a membership composed of private individuals, and that do not answer to any government. In essence, NGOs are organized interest groups that operate single or in combination with one another to promote their causes. Globally, there are well known NGOs such as Amnesty International, Green Peace, Red cross, save the children, CARE and Oxfarm. There are also Community Based Organizations (CBO), City wide Organizations and National NGOs.

\section{Rural Development}

Development is a widely participatory process of directed social change in a society, intended to bring about both social and material advancement (including greater equality, freedom and other valued qualities) for the majority of the people through their gaining greater control over their environment. Hence, development is a constant process of transformation. It is a dynamic concept denoting a state of ceaseless change.

Rural Development is the improvement of the living standards of the low-income population living in rural areas on a self-sustaining basis, through transforming the socio-spatial structures of their productive activities. In essence, rural development implies a broad based reorganization and mobilization of the rural masses so as to enhance their capacity to cope effectively with the daily tasks of their lives and with changes consequent upon this.

\section{Problems of Rural Development in Nigeria}

According to Adeyemo (2003:134), development is a broad term which indicates improvement and this improvement may be perceived from income, state of health, human reasoning, physical and social as different from the former state. Any human society is not static but dynamic in terms of the ways of life and adopted technologies. However, the rates of development differ from one society to another and from generation to generation.

Similarly, development may simply be understood as the unending improvement in the capacity of groups of individuals and societies to control and manipulate the forces of nature as well as themselves (and where necessary, other individuals and societies for their own material benefit and ultimately for the benefit of humanity at large. It is the process of actualizing man's inherent capacity to live a better and more fulfilling life. (Girigiri, 2000:111)

With the meaning of development clarified, one can now move on to examine what rural development means. World Bank (1975), asserts that rural development is concerned with the modernization and monetization of rural society, and with its transition from its traditional isolation to integration with the national economy. Todaro (1977:249), asserts that rural development encompasses:

- Improvement in levels of living, including income, employment, education, health and nutrition, housing and a variety of social services;

- Decreasing inequality in the distribution of rural incomes and in urban-rural imbalances in incomes and economic opportunities; and

- The capacity of the rural sector to sustain and accelerate the pace of these improvement. 
Akpakpan (1992:4), opined that rural development is the retransformation of rural areas of the society; i.e. the transformation of the economic, social, and political structures, institutions, relationships, and processes in the rural areas which have hindered productivity, social consciousness, and political participation in the past, and must involve measures and actions that will bring about such transformationmeasures and actions that will generate economic opportunities (e.g. jobs and incomes) and improve literacy, health, housing, real output of goods and services, techniques of production, and social and political consciousness in the rural areas of the society.

Rural development is a specific context of the development process. It is usually a directed and aided process. Rural development is an embodiment of the mechanisms and processes by which change to an improved level of economic and social life is brought to rural inhabitants. It is the process of bringing improved level of living to the rural population.

According to Olatunbosun (1975:147), Nigeria's approach to rural development has largely taken the form of agricultural development. The country has not had a co-ordinated programme of rural development. It had taken a unilateral conception of rural development, the aim of which is essentially that of modernizing agriculture. In sum, Nigeria's efforts in rural development through agricultural programmes had failed to achieve their objectives. They have been capitalist and export-oriented. Consequently, Peasant agriculture has largely been neglected and the Peasantry marginalized in agricultural policies and programmes.

Successive governments have created rural development programmes and some of the rural development programmes include:

- Operation Feed the Nation (OFN) programme of May, 1976. Under the leadership of Lt General Olusegun Obasanjo;

- The River Basin and Rural Development Authorities (RBRDA) of 1973;

- Directorate of food, Road and Rural Infrastructure (DFRRI) of 1986;

- $\quad$ Better Life for Rural Women (BLRW);

- $\quad$ The family Support Programme (FSP);

- Family Economic Advancement Programme (FEAP); and

- National Directorate of Employment (NDE).

In 1995, Olatunbosun in his study titled Nigeria's neglected rural majority, asserted that Nigeria had never had a co-ordinated programme for rural development. He recommended a multi-dimensional approach to rural development. He contended that "in order to improve the quality of life of the neglected rural majority in Nigeria, Programmes of agricultural production; health care delivery; investment in rural non-farm activities; nutrition; education training-both formal and non-formal; rural electrification; co-operatives; water supply; rural credit; entertainment; and road construction should be planned and implemented in an integrated manner, with consideration for projects that mutually support and inter-lock with one another in an overall rural development plan" (Olatunbosun, 1995:157).

Since after the colonial era, the rural sector in Nigeria has remained backward. The dispositions of the political leaders of the country towards this sector have largely been that of neglect. In spite of the stability in the national economy in the 1960's and the Oil boom of the early 1970's, the living conditions of the people in the rural sector of Nigeria have remained basically unaffected by development efforts. This situation has left Nigerian rural dwellers with diverse problems. Some of these problems as highlighted by the Better Life programme for Rural Women in 1988 quoted in Girigiri (2000:124) include lack of portable water; Health Care problem; transport problems; lack of storage and preservation facilities; Educational problem; inaccessibility to loan and credit facilities; poor return on subsistence farming; the problem of unemployment; Environmental degradation; Vagaries in Weather condition; Communal Conflict; and general poverty. 


\section{Non-Governmental Organizations: A General Overview}

Non-Governmental Organization (NGOs) are civil organizations that are largely or totally independent of government and which function as charitable or religious associations, mobilize private funds for development initiatives and programmes, raise awareness and influence policies in pursuance of the ideals of democracy and good governance as well as undertake diverse humanitarian projects that could better the lots of the grass-roots (Sandberg, 1994; Chalmer, 2002).

Iriye (2004) defines Non-Governmental Organizations as a voluntary, non-state, non-profit, nonreligious, and non-military associations. It is an independent voluntary association of people acting together on a continuous basis for some common purpose other than achieving government office, making money or illegal activities. In his view, two main types of Non-Governmental Organizations are recognized according to the activities they pursue: (i) operational NGOs that deliver services; and (ii) Campaigning NGOs.

A non-governmental organization is a legally constituted organization created by natural or legal persons that operates independently from any form of government. The term originated from the United Nations (UN) in 1945 and is normally used to refer to organizations that are not a part of a government and are not conventional profit businesses. In the cases in which NGOs are funded totally or partially by governments, the NGO maintains its non-governmental status by excluding government representatives from its membership.

Michael and David (1992), see non-governmental organizations as an organization that is not part of a government and was not founded by states. They maintained that NGOs are typically independent of government. The term is usually restricted to social, cultural, legal and environmental advocacy groups having goals that are non-commercial. They are usually non-profit organizations that gain at least a portion of their funding from private services. The World Bank (1990), sees Non-governmental organizations as private agencies; indigenous groups organized regionally or nationally and member groups in villages that support international and national development and partnering with governments in global development initiatives.

Non-Governmental organizations are classified by orientation and/or level of co-operation. NGOs by orientation include charitable orientation, service orientation, participatory, professional association, and empowering orientation. While NGO type by level of co-operation comprises of community-based organization, city wide organization, national NGO, and international non-governmental organizations.

The structure of NGOs remains the same even if their operations vary. The structures of NGOs are discussed under the following headings:

- Methods: NGOs vary in their methods. Some act primarily as lobbyist while others conduct programmes and activities.

- Staffing: Some NGOs are highly professionalized and rely mainly on paid staff. Others are based around voluntary labour and are less formalized.

- Funding:The sources of funds available to an NGO determines its budget. The major sources of NGO funding are membership dues, grants from international institutions or national grants, and private donors.

- Project management:Generally, non-governmental organizations have either a community or environmental focus. They mobiles public support and maintain strong link with community groups in developing centres.

- Public relations: Foundations and charities use good measures of public relations to raise funds. They also employ standard lobbying techniques with governments.

- Consulting: Most NGOs have a consultative status with United Nations Agencies relevant to their areas of work.

The vital role of NGOs and other major groups in sustainable development was recognized in chapter 27 of Agenda 21, leading to intense arrangements for a consultative relationship between the United Nation and non-governmental organizations. 


\section{Role of Non-Governmental Organizations (NGOs) in Rural Development in Nigeria}

Non-Governmental Organizations have played tremendous roles in rural development in Nigeria. Some of such roles include the following:

- Human Capital Development and technical assistance. They embark on the training of people in the area of skills acquisition. They also award scholarship to deserving students to study both at home and abroad. They render technical assistance to both Community Based Organizations (CBOs) and governments.

- Development of small scale farmers. They give support and assistance to small scale farmers by providing them with loans/grants. They also provide them with improved seedlings and technical advice that facilitate their growth and development.

- Research, monitoring and evaluation. They conduct research on very sensitive issues with a view to making recommendation on how to improve such situation. They also carry out the responsibility of effective monitoring and evaluation of projects.

- Enlightenment campaigns. They carry out enlightenment campaigns and sensitization programmes. Such campaigns create awareness and educate people on government policies and programmes.

- Advocacy for the poor. Advocacy NGOs shoulder the responsibility of defending the poor and promoting specific causes. In most cases, NGOs become spokespersons for the poor and attempt to influence government policies and programmes on their behalf.

- Conflict resolution and peace building. Non-governmental organizations have emerged as an indispensable partner in conflict resolution and peace building. They have complemented the efforts of governments and other stakeholders in reconciliation and peace building.

In the words of Konteh (1999), the potential strength of non-governmental organizations as an effective check to state power and dynamic agents of grassroots empowerment and development has been recognized by successive governments since independence. NGOs will continue to play a leading role in the promotion of good government, poverty alleviation, education, health, infrastructural development, promotion and defense of human rights, peace building and conflict prevention.

\section{Challenges of Non-Governmental Organizations in Nigeria}

Some of the challenges of non-governmental organizations in Nigeria include the following:

- Financial constraint. Their financial resources is made up almost exclusively of dues/contributions paid by members. Most at times, these dues and contributions are not paid regularly by members which affects their growth and also prevents them from performing their legitimate roles effectively.

- Leadership. Non-Governmental Organizations in Nigeria lack efficient leadership. They are characterized by illiterate and inexperienced leaders who lack requisite knowledge and managerial ability to pilot their affairs.

- Corruption. There is large-scale misappropriation, embezzlement of funds (gifts and dues) and other unprogressive activities. The prevalence of widespread corruption limits their scope of activities and impede their growth.

- Tribalism, ethnicity and nepotism. Nigeria is an heterogeneous society and as a mater of fact, tribalism, ethnicity and nepotism are canker-worms that have eaten deep into the social fabric of the society. This problem has adversely affected the performance of non-governmental organizations in Nigeria.

- Insecurity. There is high-level and widespread insecurity in the country that has led to the wanton destruction of lives and property is also a major factor that has hampered the progress of nongovernmental organizations. 


\section{Conclusion}

In conclusion, Non-Governmental organizations are largely or totally independent of government, and they exist for a variety of reasons, usually to further the political or social goals of their members or funders. They function as charitable or religious associations, mobilize private funds for development initiatives and programmes, raise awareness and influence policies in pursuance of the ideals of democracy, good governance as well a undertake diverse humanitarian projects that could better the lots of the grassroots. Examples include improving the state of the national environment, encouraging the observance of human rights, improving the welfare of the disadvantaged, or representing a corporate agenda. However, there are a huge number of such organizations and their goals cover a broad range of political and philosophical positions.

\section{Recommendation}

Based on the findings of this study, it has been recommended that:

- Government should embark on aggressive development of the rural area. Such action will improve the standard of living of rural dwellers. It will equally help to check the rate of rural-urban migration and also attract investors to the rural area.

- There should be collaboration among the different levels of NGOs. There should be a high level of collaboration among the various levels of NGOs such as community based organizations, citywide organizations, National NGOs, and international NGOs. Such collaboration will enable them to work together through strategic partnership.

\section{References}

Adeyemo, M.A. (2003), Development and underdevelopment in a comparative perspective. PortHarcourt: Anethyst and Colleagues Press.

Akpakpan, E.B. (1987), Cross roads in Nigerian development: A programme of action for a better Nigeria. Port Harcourt: New Generation Publishers.

Arvind, S. and Everett, M.R. (1989), "India's information revolution", New Delhi, Sage; in Evolution of Development and

Development Administration Theory; The Indian Journal of Public Administration, Vol. xxxv, No. 4.

Chilcote, R.H. (1984), Theories of development and underdevelopment. London: West View Press.

David, L. and Nazneen, K. (2009), Non-Governmental Organizations and Development. New York: Rutledge.

Girigiri, B.K. (2000), A sociology of rural life in Africa. Owerri: Springfield Publishers.

Grant, B.S. (2007), Global Standard NGOs. Geneva: Lulu Publishers.

Guler A.D. (2010), NGOs and social responsibility. Bingley, UK: Emerald.

Olatunbosun, D. (1975), Nigeria's rural majority. Ibadan: Ibadan University Press.

Rourke, J.T. (2008), International Politics on the World Stage. New York: McGraw-Hill.

Tamuno, S.T. (2009), Rural development in Rivers State: An effective approach. PortHarcourt: Paragraphics.

UNDP (1990). The 1990 Human development report of the United Nations Development programme (UNDP) for Africa. 